\title{
Hubungan Riwayat Bayi Berat Lahir Rendah dan Jumlah Anak dalam Keluarga dengan Kejadian Stunting Usia 12-59 Bulan di Desa Panyirapan Kabupaten Bandung
}

\author{
Annisa Kusumawardhani, ${ }^{1}$ Waya Nurruhyuliawati, ${ }^{2}$ Herry Garna ${ }^{3}$ \\ ${ }^{1}$ Prodi Pendidikan Dokter, Fakultas Kedokteran, Universitas Islam Bandung, \\ ${ }^{2}$ Departemen Saraf, Fakultas Kedokteran, Universitas Islam Bandung, \\ ${ }^{3}$ Departemen Anak, Fakultas Kedokteran, Universitas Islam Bandung
}

\begin{abstract}
Abstrak
Stunting merupakan permasalahan global yang sedang marak belakangan ini. Hal ini mengindikasikan terdapat berbagai faktor yang dapat menyebabkan stunting. Berat badan lahir rendah merupakan faktor prenatal yang mungkin berhubungan dengan pertumbuhan anak di kemudian hari. Faktor sosial-ekonomi seperti jumlah anak dalam keluarga juga dapat memengaruhi pertumbuhan anak. Tujuan penelitian ini adalah menganalisis hubungan riwayat berat badan lahir rendah dan jumlah anak dalam keluarga dengan kejadian stunting di Desa Panyirapan Kabupaten Bandung periode Maret-Agustus 2019. Subjek penelitian adalah anak usia 12-59 bulan. Penelitian menggunakan rancangan kualitatif metode analitik komparatif dengan pendekatan case control. Uji statistik menggunakan uji chi-square dan Eksak Fisher. Jumlah responden pada penelitian ini adalah 49 anak stunting dan 43 anak tidak stunting. Anak stunting dengan riwayat berat badan lahir rendah sebanyak 5 anak (10\%) dan tidak terdapat hubungan bermakna ( $\mathrm{p}=0,209)$. Anak stunting dengan jumlah anak >2 sebanyak 17 anak (35\%) dan terdapat hubungan bermakna $(\mathrm{p}=0,008 ; \mathrm{OR}=5,18)$. Simpulan, tidak terdapat hubungan antara berat badan lahir rendah dan kejadian stunting, tetapi terdapat hubungan jumlah anak dalam keluarga dengan kejadian stunting anak usia 12-59 bulan di Desa Panyirapan Kabupaten Bandung.
\end{abstract}

Kata kunci: Bayi berat lahir rendah, jumlah anak, stunting, usia 12-59 bulan

\section{The Relationship between Low Birth Weight and Number of Children with Stunting in Children Aged 12-59 Months in Panyirapan Village, Bandung Regency}

\begin{abstract}
Stunting is a global problem that become a trending these days. This indicates there are factors that can cause stunting. Low birth weight is a prenatal factor that may relate with children development in the future. Social-economic factor such as number of children may also affect the growth of children. The purpose of this study was to analyze the relationship between low birth weight and number of children with stunting in Panyirapan Village, Bandung Regency in March-August 2019. Subjects were children aged 12-59 months. This study used qualitative comparative method using case control. Statistical test using chi-square and Fisher's exact test. Total sample for this study were 49 stunting children and 43 non-stunting children. Stunting children with low birth weight history were 5 children $(10 \%)$, and after being tested there was no significant relationship ( $p$-score $=0.209)$. Stunting children with number of children >2 were 17 children (35\%), and after being tested there was significant relationship ( $\mathrm{p}$-score=0.008; $\mathrm{OR}=5,18$ ). In conclusion, there is no relationship between low birth weight and stunting, but there is a relationship between number of children and stunting in children aged 12-59 months in Panyirapan Village, Bandung Regency.
\end{abstract}

Keywords: Aged 12-59 months, low birth weight, number of children, stunting,

Korespondensi: Annisa Kusumawardhani. Program Studi Pendidikan Dokter, Fakultas Kedokteran, Universitas Islam Bandung. Jl. Tamansari no. 22, 40116, Kota Bandung, Provinsi Jawa Barat. 


\section{Pendahuluan}

Kejadian stunting merupakan permasalahan global yang sedang marak akhir-akhir ini. Berdasar atas data yang telah dilaporkan ke Unicef, tahun 2017 sekitar 151 juta anak balita di diagnosis sangat pendek. Menurut hasil Riset Kesehatan Dasar (Riskesdas) Indonesia tahun 2018, prevalensi balita pendek sebesar 11,5\% dan balita sangat pendek sebesar 19,3\% dengan provinsi kejadian stunting tertinggi di Nusa Tenggara Timur dengan angka kejadian mencapai $42,6 \% .^{1}$ Menurut Profil Kesehatan Jawa Barat tahun 2016 kejadian stunting terdata sebanyak 35,3\% dengan prevalensi di Kabupaten Bandung Barat sebanyak 7,84\%. ${ }^{2}$

Stunting atau perawakan pendek adalah keadaan gangguan proses pertumbuhan anak yang disebabkan oleh asupan nutrisi yang kurang atau infeksi berulang. ${ }^{3}$ Seorang balita dinyatakan pendek apabila hasil pengukuran tinggi badan per usia (TB/U) kurang dari -2SD dan dinyatakan sangat pendek apabila kurang dari -3 SD. Terdapat faktor risiko utama yang dapat menyebabkan kejadian stunting, yaitu kemiskinan, sosial dan budaya, peningkatan paparan terhadap penyakit infeksi, kerawanan pangan, serta akses masyarakat ke tempat pelayanan kesehatan. ${ }^{4}$ Salah satu faktor lain yang menyebabkannya adalah bayi berat lahir rendah (BBLR). Bayi berat lahir rendah (BBLR) merupakan keadaan bayi lahir dengan berat kurang dari 2.500 gram. ${ }^{4}$ Berat badan lahir rendah merupakan indikator status kesehatan masyarakat karena mempunyai korelasi dengan angka morbiditas, mortilitas, dan kejadian gizi kurang di kemudian hari. ${ }^{5}$ Berdasar atas penelitian Arnisam ${ }^{6}$ menunjukkan bahwa seseorang dengan riwayat BBLR memiliki risiko 3,34 kali lebih besar untuk mengalami status gizi kurang.

Selain riwayat BBLR, faktor sosioekonomi dan budaya juga menjadi penyebab stunting. Status gizi balita berkaitan erat dengan kondisi sosioekonomi dan budaya, antara lain pendidikan orangtua, pekerjaan orangtua, jumlah anak dalam keluarga yang menjadi tanggungan, pola asuh ibu, serta kondisi ekonomi orangtua. ${ }^{7}$ Berdasar atas buku Pendekatan Keluarga dalam Pencapaian Prioritas Pembangunan Kesehatan tahun 2017, untuk menandakan suatu keluarga itu sehat atau tidak digunakan sejumlah indikator. Salah satu indikator, yaitu keluarga mengikuti program Keluarga Berencana (KB).

Berdasar atas latar belakang tersebut di atas, peneliti bermaksud menganalisis hubungan riwayat bayi berat lahir rendah (BBLR) dan jumlah anak dalam keluarga dengan kejadian stunting di Desa Panyirapan Kabupaten Bandung.

\section{Metode}

Penelitian menggunakan rancangan kualitatif metode analitik komparatif dengan pendekatan case control. Populasi target pada penelitian ini adalah anak stunting dan normal usia (12-59 bulan) yang datang ke Posyandu di Desa Panyirapan Kabupaten Bandung Provinsi Jawa Barat periode Maret-Agustus 2019.

Subjek penelitian berjumlah 92, yaitu 49 anak stunting dan 43 anak tidak stunting. Teknik pemilihan sampel dalam penelitian ini adalah total sampling. Semua sampel yang datang dan memenuhi kriteria inklusi dan eksklusi dimasukkan ke dalam penelitian. Kriteria inklusi kasus adalah anak usia 12-59 bulan, tinggal di wilayah penelitian, dan termasuk kriteria stunting. Kriteria inklusi kontrol adalah anak usia 12-59 bulan, tinggal di wilayah penelitian, dan tidak termasuk kriteria stunting. Kriteria eksklusi anak yang memiliki kelainan kromosom dan anak yang memiliki kelainan deformitas (mempengaruhi tinggi).

Jumlah sampel yang diambil pada penelitian ini ditentukan dengan menggunakan rumus analitik komparatif kategorikal tidak berpasangan beda proporsi. Dari perhitungan rumus didapat $n=39$ untuk variabel berat badan lahir rendah dan $n=23$ untuk variabel jumlah anak dalam keluarga.

Variabel penelitian terdiri atas berat badan lahir rendah, jumlah anak dalam keluarga, dan stunting. Berat badan lahir dikategorikan menjadi dua kelompok, yaitu berat badan lahir $<2.500$ gram dan berat badan lahir $\geq 2.500$ gram. Jumlah anak dalam keluarga dikategorikan menjadi dua kelompok, yaitu jumlah anak dalam keluarga $>2$ dan jumlah anak dalam keluarga $\leq 2$.

Pengumpulan data diambil dengan menggunakan pengisian form yang dilakukan oleh orangtua/wali dari subjek penelitian. Data yang sudah terkumpul kemudian diolah secara komputerisasi. Langkah dalam pengolahan data meliputi editing untuk memeriksa data yang diperlukan terhadap kelengkapan dan ketidaksesuaian informasi, kemudian coding dilakukan untuk mengubah data yang akan berguna untuk data entry, kemudian data entry dimasukkan ke dalam program statistical product and service solution (SPSS), dan terakhir adalah cleaning, yaitu pengecekan ulang untuk melihat kesalahan dan ketidaklengkapan yang kemudian dilakukan koreksi. Uji statistik yang digunakan adalah chi-square dan Eksak Fisher.

Penelitian ini mendapatkan kajian etik dari Komite Etik Penelitian Kesehatan Fakultas Kedokteran Universitas Islam Bandung Nomor: 114/Komite Etik. FK/IV/2018.

\section{Hasil}

Berdasar Tabel 1 dari jumlah 92 responden yang menjadi subjek penelitian di Desa Panyirapan, usia yang mendominasi penderita stunting adalah usia $>36$ bulan sebanyak 30 anak (61\%). Jenis kelamin penderita stunting dan tidak stunting hampir sama antara laki-laki dan perempuan. Pendidikan terakhir ibu, status pekerjaan ibu, usia ibu saat hamil, tinggi badan ibu, juga riwayat pemberian ASI eksklusif tidak berbeda antara stunting dan tidak stunting. 
Tabel 1 Karakteristik Umum Subjek Penelitian berdasar atas Usia, Jenis Kelamin, Pendidikan Terakhir Ibu, Status Pekerjaan Ibu, Usia Ibu Saat Hamil, Tinggi Badan Ibu, dan Riwayat Pemberian ASI Eksklusif (n=92)

\begin{tabular}{|c|c|c|c|c|c|}
\hline \multirow{2}{*}{ Karakteristik } & \multicolumn{2}{|c|}{ Stunting } & \multicolumn{2}{|c|}{$\begin{array}{c}\text { Tidak } \\
\text { Stunting }\end{array}$} & \multirow{2}{*}{ Nilai p } \\
\hline & $n=49$ & $\%$ & $n=43$ & $\%$ & \\
\hline \multicolumn{6}{|l|}{ Usia (bulan) } \\
\hline $12-36$ & 19 & 39 & 18 & 42 & \\
\hline $37-48$ & 12 & 24 & 6 & 14 & $0,434^{*}$ \\
\hline $49-59$ & 18 & 37 & 19 & 44 & \\
\hline Jenis kelamin & & & & & \\
\hline Laki-laki & 26 & 53 & 19 & 44 & $0,396^{*}$ \\
\hline Perempuan & 23 & 47 & 24 & 56 & \\
\hline Pendidikan terakhir ibu & & & & & \\
\hline SD & 15 & 31 & 13 & 30 & \\
\hline SMP & 19 & 39 & 17 & 40 & $0,971^{*}$ \\
\hline SMA & 13 & 26 & 12 & 28 & \\
\hline$>$ SMA & 2 & 4 & 1 & 2 & \\
\hline Status pekerjaan ibu & & & & & \\
\hline Bekerja & 15 & 31 & 12 & 28 & $0,776^{*}$ \\
\hline Tidak bekerja & 34 & 69 & 31 & 72 & \\
\hline $\begin{array}{l}\text { Usia ibu saat hamil } \\
\text { (tahun) }\end{array}$ & & & & & \\
\hline$\leq 20$ & 6 & 12 & 5 & 12 & $0,927^{*}$ \\
\hline$>20$ & 43 & 88 & 38 & 88 & \\
\hline Tinggi badan ibu (cm) & & & & & \\
\hline$<150$ & 19 & 39 & 11 & 26 & $0,178^{*}$ \\
\hline$\geq 150$ & 30 & 61 & 32 & 74 & \\
\hline $\begin{array}{l}\text { Riwayat pemberian ASI } \\
\text { eksklusif }\end{array}$ & & & & & \\
\hline $\mathrm{Ya}$ & 44 & 90 & 43 & 100 & $0,058^{* *}$ \\
\hline Tidak & 5 & 10 & o & o & \\
\hline
\end{tabular}

Keterangan: ${ }^{*}=$ uji chi-square ${ }^{* *}=$ Uji Eksak Fisher

Tabel 2 Hubungan BBLR dan Jumlah Anak dalam Keluarga dengan Stunting

\begin{tabular}{|c|c|c|c|c|}
\hline \multirow{2}{*}{$\begin{array}{l}\text { BBLR dan } \\
\text { Jumlah } \\
\text { Anak dalam } \\
\text { Keluarga }\end{array}$} & Stunting & $\begin{array}{c}\text { Tidak } \\
\text { Stunting }\end{array}$ & \multirow{2}{*}{ Nilai p } & \multirow{2}{*}{$\begin{array}{c}\text { OR } \\
\text { (IK 95\%) }\end{array}$} \\
\hline & $n=49(\%)$ & $n=43(\%)$ & & \\
\hline \multicolumn{5}{|l|}{$\begin{array}{l}\text { Berat badan lahir } \\
\text { (gram) }\end{array}$} \\
\hline$\leq 2500$ & $5(10)$ & $1(2)$ & \multirow[b]{2}{*}{$0,209^{*}$} & \\
\hline$>2500$ & $44(90)$ & $42(98)$ & & $\begin{array}{c}4,80 \\
(0,53- \\
42,57)^{*}\end{array}$ \\
\hline \multicolumn{5}{|l|}{$\begin{array}{l}\text { Jumlah anak } \\
\text { dalam keluarga }\end{array}$} \\
\hline$>2$ & $17(35)$ & 39 (91) & $0,004^{*}$ & $\begin{array}{c}5,18 \\
(1,58- \\
16,95)^{*}\end{array}$ \\
\hline
\end{tabular}

Keterangan: * =analisis bivariat

Tabel 2 menggambarkan hasil akhir perhitungan analisis bivariat dengan variabel bebas utama adalah BBLR dan jumlah anak dalam keluarga. Variabel yang memiliki hubungan yang bermakna dengan kejadian stunting adalah jumlah anak dalam keluarga $(\mathrm{p}=0,004$; $\mathrm{OR}=5,18 ; \mathrm{IK}=1,58-16,95)$. Nilai odds ratio adalah 5,18 artinya kemungkinan (odds) anak dalam keluarga yang jumlah anak >2 mengalami kejadian stunting 5,18 kali dibanding dengan anak dalam keluarga yang jumlah anak $\leq 2$.

\section{Pembahasan}

Kejadian stunting lebih banyak terjadi pada anak usia $>36$ bulan (61\%). Hal ini sesuai dengan penelitian Hanum dan Khomsan ${ }^{8}$ di Cianjur yang mendapatkan stunting lebih banyak pada usia 48-59 (29,8\%). Hal ini diduga disebabkan oleh semakin tinggi usia anak maka kebutuhan energi juga semakin tinggi.

Pada kelompok responden yang stunting dan tidak stunting distribusi jenis kelamin laki-laki dan perempuan tersebar rata, tidak terdapat hubungan signifikan antara laki-laki dan perempuan dengan stunting. Hal ini sejalan dengan penelitian yang dilakukan Karundeng dkk. ${ }^{9}$ di Puskesmas Kao Kecamatan Kao Kabupaten Halmahera Utara. Hal ini juga sejalan dengan penelitian Lestari dkk..$^{10} \mathrm{di}$ Kabupaten Asahan. Penelitian ini tidak sejalan dengan penelitian Hanum dan Khomsan ${ }^{8}$ yang menunjukkan bahwa kejadian stunting lebih banyak mengenai anak laki-laki dibanding dengan perempuan.

Tidak terdapat hubungan antara tingkat pendidikan ibu dan kejadian stunting. Hal ini sejalan dengan penelitian Aramico dkk. ${ }^{11} \mathrm{Hal}$ ini tidak sejalan dengan hasil penelitian Putri $^{7}$ karena terdapat hubungan bermakna $(p=0,022)$. Hal ini juga tidak sejalan dengan penelitian Ni'mah dan Muniroh ${ }^{12}$ Kabupaten Bojonegoro. Berdasar literatur, semakin tinggi tingkat pendidikan ibu maka semakin mudah untuk diberikan edukasi mengenai cara pemberian asupan gizi yang benar dan mengimplementasikan pengetahuannya kepada anak. Dengan demikian, pendidikan ibu yang relatif rendah akan menyebabkan anak mengalami stunting di kemudian hari. ${ }^{5}$

Tidak terdapat hubungan antara status pekerjaan ibu dan kejadian stunting. Hal ini sejalan dengan penelitian Ibrahim dan Faramita ${ }^{13}$ di Kota Makassar. Tetapi hal ini tidak sejalan dengan penelitian Putri ${ }^{7}$ di wilayah Puskesmas Nanggalo Padang. Status pekerjaan ibu dapat memengaruhi asupan gizi balita karena ibu yang bekerja biasanya tidak memiliki waktu yang cukup untuk mengasuh dan mengatur pola makan anaknya sehingga dapat menyebabkan gizi anak menjadi kurang. Umumnya ibu yang bekerja memberikan perhatian lebih sedikit kepada anaknya. ${ }^{8}$

Tidak terdapat hubungan antara usia ibu saat hamil dan kejadian stunting. Hal ini sesuai dengan penelitian Rosha dkk. ${ }^{5}$ bahwa tidak terdapat hubungan. Hasil penelitian menunjukkan nilai $\mathrm{p}=0,24(\mathrm{p}>0,05)$ pada riskesdas tahun 2007 dan $\mathrm{p}=0,23$ pada riskesdas tahun 2010 artinya tidak terdapat hubungan antara usia ibu saat hamil dan kejadian stunting.

Tidak terdapat hubungan tinggi badan ibu $\geq 150$ cm dan tinggi badan ibu $<150 \mathrm{~cm}$ dengan kejadian stunting. Hal ini sesuai dengan penelitian Hanum dan Khomsan ${ }^{8}$ tidak terdapat hubungan asupan gizi dan tinggi badan ibu dengan status gizi anak balita $(\mathrm{p}=0,562)$. Hal ini juga sejalan dengan penelitian Nugroho ${ }^{14}$ di Kota Bandar Lampung. Hal ini tidak sesuai 
dengan penelitian di perkotaan oleh Aridiyah dkk. ${ }^{3}$ bahwa terdapat hubungan antara tinggi badan ibu dan kejadian stunting. Bila salah satu atau kedua orangtua pendek karena memiliki kelainan gen kromosom yang membawa sifat pendek mengakibatkan anak menjadi stunting.

Tidak terdapat hubungan yang bermakna antara riwayat pemberian ASI eksklusif dan stunting $(\mathrm{p}=0,058)$. Hal ini sejalan dengan penelitian yang dilakukan Azmii dan Arini ${ }^{15}$ di Puskesmas Sukmajaya. Tetapi hal ini tidak sejalan dengan penelitian yang dilakukan Hendra dkk. ${ }^{16}$ di Aceh. Peneliti menemukan bahwa proporsi balita yang mengalami stunting lebih banyak pada anak yang pemberian ASI tidak eksklusif (75\%) daripada anak yang diberikan ASI eksklusif $(\mathrm{p}=0,002)$. Hal ini juga tidak sejalan dengan penelitian Pangalila dkk. ${ }^{17}$ di Kabupaten Minahasa bahwa terdapat hubungan bermakna. Pemberian ASI yang baik oleh ibu membantu menjaga keseimbangan gizi anak sehingga tercapai pertumbuhan yang normal. ${ }^{3}$

Hasil penelitian menunjukkan bahwa tidak terdapat hubungan yang bermakna antara BBLR dan kejadian stunting $(\mathrm{p}=0,209)$. Hal ini sesuai dengan penelitian yang dilakukan Aridiyah dkk. ${ }^{3}$ yang membandingkan faktor-faktor yang memengaruhi kejadian stunting anak balita di wilayah pedesaan dengan wilayah perkotaan. Tetapi hal ini tidak sejalan dengan penelitian Sherlla dkk. ${ }^{18}$ di Kota Surakarta. Hal ini juga tidak sejalan dengan penelitian Fitri ${ }^{19}$ di Pekanbaru. Hasil penelitian bertentangan dengan teori bahwa berat badan lahir dapat menjadi penentu kuat terhadap pertumbuhan anak di kemudian hari karena umumnya anak dengan riwayat berat badan lahir rendah sulit mengejar pertumbuhan normal saat masa kanak-kanak. ${ }^{20}$

Hasil penelitian menunjukkan terdapat hubungan bermakna antara jumlah anak dalam keluarga dan stunting $(\mathrm{p}=0,004)$. Hal ini sejalan dengan penelitian Putri $^{7}$ di Puskesmas Nanggalo Padang bahwa terdapat hubungan. Hal ini juga sejalan dengan penelitian yang dilakukan Zilda dan Sudiarti ${ }^{11}$ di Sumatera pada balita usia 24-59 bulan. Namun, hasil penelitian tidak sejalan dengan penelitian Aridiyah dkk. ${ }^{3}$ di Kabupaten Jember. Hal ini bertentangan dengan teori yang ada. Ketersediaan makanan pada keluarga dengan jumlah anak lebih banyak umumnya lebih sedikit bila dibanding dengan jumlah anak dalam keluarga cukup. Distribusi makanan yang tidak merata terhadap seluruh anggota keluarga dapat menyebabkan anak balita dalam keluarga menderita kurang gizi.7,20

\section{Simpulan}

Berdasar penelitian di atas dapat disimpulkan bahwa tidak terdapat hubungan riwayat bayi berat lahir rendah (BBLR) dengan kejadian stunting, tetapi terdapat hubungan antara jumlah anak dalam keluarga dan kejadian stunting pada anak usia 12-59 bulan di Desa Panyirapan Kabupaten Bandung.

\section{Ucapan Terima kasih}

Ucapan terima kasih kepada Dinas Kesehatan Kabupaten Bandung, Kepala Puskesmas Soreang, Ibu Nita selaku bidan Desa Panyirapan, Ibu Juju selaku ketua PKK Desa Panyirapan.

\section{Daftar Pustaka}

1. Kementrian Kesehatan RI. Hasil utama Riskesdas 2018. Jakarta: Kemenkes RI; 2018.

2. Dinkes Jawa Barat. Profil Kesehatan Jawa Barat 2016. Bandung: Dinkes Jabar; 2016.

3. Aridiyah FO, Rohmawati N, Ririanty M. Faktorfaktor yang mempengaruhi kejadian stunting pada anak balita di wilayah pedesaan dan perkotaan. J Pustaka Kesehat. 2015;3(1):163-70.

4. Mahayana SAS, Chundrayetti E, Yulistini. Faktor risiko yang berpengaruh terhadap kejadian berat badan lahir rendah di RSUP Dr. Djamil Padang. 2015;4(3):664-73. [diunduh 27 Januari 2019]. Tersedia dari: http://jurnal.fk.unand.ac.id/index. php/jka/article/view/345/300.

5. Rosha BC, Sisca D, Putri K, Yunita I, Putri S. Determinan status gizi pendek anak balita dengan riwayat berat badan lahir rendah (BBLR) di Indonesia (analisis data Riskesdas 2007-2010). J Eko Kesehat. 2013;12(3):195-205.

6. Arnisam. Hubungan berat badan lahir rendah (BBLR) dengan status gizi anak usia 6-24 bulan. Yogyakarta: UGM; 2007.[diunduh 4 Februari 2019]. Tersedia dari: http://etd.repository.ugm. ac.id/ PenelitianDetail\&act=view.

7. Putri RFD. Penelitian faktor-faktor yang berhubungan dengan status gizi anak balita di wilayah kerja Puskesmas Nanggalo Padang. J Kesehat Andalas. 2015;4(1):254-61.

8. Hanum F, Khomsan A. Hubungan asupan gizi dan tinggi badan ibu dengan status gizi anak balita. J Gizi Pangan. 2014;9(1):1-6.

9. Karundeng L, Ismanto A, Kundre R. Hubungan jarak kelahiran dan jumlah anak dengan status gizi balita di Puskesmas Kao Kecamatan Kao Kabupaten Halmahera Utara. J Keperawatan UNSRAT. 2015;3(1):1-9.

10. Lestari W, Rezeki SHI, Siregar DM, Manggabarani S. Faktor yang berhubungan dengan kejadian stunting pada anak sekolah dasar negeri 014610 Sei Renggas Kecamatan Kisaran Barat Kabupaten Asahan. J Dunia Gizi. 2018;1(1):59-64.

11. Aramico B, Sudargo T, Susilo J. Hubungan sosial ekonomi, pola asuh, pola makan dengan stunting pada siswa sekolah dasar di Kecamatan Lut Tawar, Kabupaten Aceh Tengah. J Gizi Diet Indones. 2016;1(3):121-30.

12. Ni'mah C, Muniroh L. Hubungan tingkat pendidikan, tingkat pengetahuan dan pola asuh ibu dengan wasting dan stunting pada balita keluarga miskin. Media Gizi Indones. 2015;10(1):84-90.

13. Ibrahim IA, Faramita R. Hubungan faktor sosial ekonomi keluarga dengan kejadian stunting anak usia 24-59 bulan di wilayah kerja Puskesmas Barombong Kota Makassar Tahun 2014. 2015;7:63-75.

14. Nugroho A. Determinan growth failure (stunting) pada anak umur $1 \mathrm{~s} / \mathrm{d} 3$ tahun (studi di kecamatan Tanjungkarang Barat Kota Bandar Lampung). J Kesehatan. 2016;7(3):470-9. 
15. Azmii F, Arini FA. Karakteristik ibu, riwayat ASI eksklusif, dan riwayat penyakit infeksi dengan kejadian stunting pada balita usia 12-59 bulan di wilayah kerja Puskesmas Sukmajaya. J Medika Respati. 2018;13:17-23.

16. Hendra A, Rahmad A, Miko A. Kajian stunting pada anak balita berdasarkan pola asuh dan pendapat keluarga di Kota Banda Aceh. J Kesmas Indones. 2016;8:63-79.

17. Pangalila YV, Punuh MI, Kapantow NH. Hubungan antara riwayat pemberian ASI eksklusif dengan kejadian stunting pada anak batita di Wilayah Kerja Puskesmas Kawangkoan Kabupaten
Minahasa. 2019:8. [diunduh 12 Januari 2020]. Tersedia dari: fkm.unsrat.ac.id/wp-content/ uploads/2014/11/Winny-Artikel.pdf.

18. Sherlla F, Lubis M, Cilmiaty R, Magna A. Hubungan beberapa faktor dengan stunting pada balita berat badan lahir rendah. J Kesehatan Kusuma Husada. 2018:13-8.

19. Fitri L. Hubungan bblr dan asi ekslusif dengan kejadian stunting di Puskesmas Lima Puluh Pekanbaru. J Endur. 2018;3(1):131-7.

20. Zilda O, Sudiarti T. Faktor risiko stunting pada balita (24-59 bulan) di Sumatera. J Gizi Pangan. 2013;8(3):175-80. 